УДК 792.03"18/19":[821.161.2-2Кар+821.161.1-2Чех](045)

ORCID ID: 0000-0002-5924-3766

Шестакова Дар'я Вікторівна,

старший викладач кафедри театрознавства. Київський національний університет театру, кіно і телебачення імені І. К. Карпенка-Карого, Київ

Шестакова Дарья Викторовна, старший преподаватель кафедры театроведения. Киевский национальный университет театра, кино и телевидения имени И. К. Карпенко-Карого, Киев

Daria Shestakova, Senior Lecturer of Theater Studies Departament. National I. K. Karpenko-Karyi Theater, Cinema and Television University, Kyiv

\title{
А. ЧЕХОВ ТА І. КАРПЕНКО-КАРИЙ: РЕФОРМА ДРАМАТУРГІЇ ТА СЦЕНІЧНОЇ ПРАКТИКИ. ОСНОВНІ АСПЕКТИ
}

\begin{abstract}
Анотація. У цій праці пропонується поглянути на постаті А.Чехова та I. Карпенка-Карого як на драматургів-реформаторів. Авторка зважає на соціокультурний контекст, в якому формувався і працював кожен з них. У дослідженні відбувається порівняльний аналіз драматургічної спадщини А. Чехова та I. Карпенка-Карого і визначаються основні аспекти реформи .

У результаті аналізу очевидним стає новаторський потенціал їхніх драматичних творів. Він розмикає базові для кожного 3 них естетичні системи і розкривається у нових тенденціях театрального мислення.

Ключові слова: п’єси I. Карпенка-Карого, драматургія А. Чехова, театральна реформа, сценічність п’єси, психологізація образу.
\end{abstract}

15 вересня 1907 року у Берліні, куди виїхав на лікування, на руках своєї дружини, помер відомий діяч української театральної культури Іван Карпович Карпенко-Карий. За три роки до цієї події, влітку 1904 року, на німецькому курорті Баденвайлер, де перебував разом із дружиною, закінчив свій земний шлях Антон Павлович Чехов. Та поєднують ці дві постаті не лише дуже схожі сценарії фіналу їхніх життів.

Постановка проблеми та актуальність дослідження. Класичні тексти перманентно проходять випробування часом, де можливі радикальні коливання у ставленні до них: від повного забуття до прискіпливої уваги. Драматургія А. Чехова та I. Карпенка-Карого вже кілька століть як залучена до орбіти світового театру, і кожний новий етап пропонує свій погляд на їхні твори, актуалізуючи увагу до них. Зазвичай їхню творчість не прийнято порівнювати, адже досі не сформовано прямого асоціативного зв'язку між їх творчими особистостями. На відміну від, скажімо, драматургії О. Островського, з природою реалізму якого часто порівнюють твори Карпенка-Карого або А. Шніцлєра, якого вважають австрійським Чеховим. Дане дослідження актуалізує можливість проаналізувати драматургічну творчість А. Чехова та I. Карпенка-Карого як своєрідну бінарну систему, беручи до уваги соціокультурний контекст, в рамках якого формувалися їхні творчі особистості.

Mema даної праці полягає у визначенні основних аспектів реформи драматургічного матеріалу у п’єсах I. Карпенка-Карого та А. Чехова та вплив цієї реформи на оновлення засобів сценічної виразності. У дослідженні застосовувалося кілька методів, зокрема, формальний, історичний та метод порівняльного аналізу як базовий. Об' $\boldsymbol{\epsilon}$ том стали, власне, твори зазначених драматургів, а предметом дослідження - порівняння драма- 
тургічної спадщини I. Карпенка-Карого й А. Чехова в контексті їхньої реформаторської спрямованості.

Аналіз досліджень і публікацій. У своїй праці авторка спирається на літературу, присвячену аналізу драматургічної спадщини А. Чехова та I. Карпенка-Карого. Це і монографії, які висвітлюють певні аспекти їхньої творчості, і статті у збірках, де творчість кожного з них розглядається у контексті певної проблематики, і матеріали конференцій різних років, які презентують дослідження фахівців у галузі театрознавства і літературознавства. Інформація із цих джерел надає можливість охарактеризувати творчість авторів, взятих до уваги у цій праці; виокремити оригінальні риси їхніх творчих шляхів і методів. Також для цього дослідження важливим джерелом інформації стали свідчення щодо акторської діяльності І. Карпенка-Карого (цей досвід вплинув на його подальшу драматургічну діяльність) $\mathrm{i}$ згадки про прецеденти перших постановок чеховської драматургії, в яких вже виявився іiї реформаторський потенціал. Попри існування значної кількості досліджень їхньої творчості, драматургічної, зокрема, імена Чехова і Карпенка-Карого розглядаються у них лише як автономні явища. Використовуючи цей аналітичний матеріал, авторка статті, вперше, виокремлюючи унікальні та спільні риси в їхній драматургії, вибудовує контекстуальний ряд, в якому твори А. Чехова та I. Карпенка-Карого розглядаються в єдиному проблемному полі.

Якщо думка про те, що драматургія А. Чехова стала переворотом у сценічному мистецтві і ознаменувала народження нової театральної системи, визначальної для ХХ століття (Зингерман, 2001) сприймається вже майже як трюїзм, то творчість I. Карпенка-Карого не викликає таких прямих асоціацій із театральною реформою, залишаючись, скоріше, замкненою в контексті традицій театру корифеїв, у яку вона органічно вкорінена. У рамках цієї праці пропонується поглянути на його драматургічну спадщину як на твори, у яких відбувалося поступове і не таке радикальне, як у його молодшого сучасника А. Чехова, реформування чинних для свого часу театральних правил.

Творчість I. Карпенка-Карого, безперечно, логічно розглядати не лише в контексті української театральної культури, а й у річищі європейської соціально-психологічної драматургії та реалістичного театру (Коломієць, 2008), у органічному зв'язку із творами М. Гоголя, Г. Ібсена, О. Островського і того ж таки А. Чехова.
Якщо драматургічна реформа Чехова, яка стала серйозним випробуванням для практиків театру межі XIX-XX століть, базувалася на спостереженнях за сучасним для нього театральним життям, за тими правилами, що ними керувалися при грі та постановках, що і викликало в результаті бажання ці правила змінити, — то витоки реформування драматургії українським корифеєм можна вбачати у його власній акторській і режисерській практиці.

Іван Карпенко-Карий починав працювати у театрі саме як актор ще у 1863 році, коли переїхав у Бобринець i, зблизившись із М. Кропивницьким, грав у любительських спектаклях. Та його артистичне життя було нетривалим. Лише після арешту, заслання, гласного нагляду поліції, позбавлений можливості брати участь у театрі як актор і режисер, він розпочинає драматургічну діяльність (Волошин, 1973). Дослідники його творчості, спираючись на враження сучасників, звертають увагу на своєрідність його виконавської манери. Так, Р. Коломієць (2008) відзначає майстерність психологічного нюансування, граничну достовірність сценічної поведінки $\mathrm{i}$, використовуючи цитату 3 однієї з літературно-критичних статей С. Єфремова, відзначає «ту скромність та простоту благородну, що самі не б' ють у вічі, але виховують глядача, лишаючи по собі глибокий слід, а не феєрверковий тільки ефект» (с. 68). Схожі думки висловлює актор I. Мар'яненко (1954) у своїх спогадах, наголошуючи на простоті у виконанні ролей I. Карпенком-Карим - без мелодраматизму i зовнішніх перебільшень, щоправда, зазначає, що «економні сценічні засоби, які він використовував, могли сприйматися навіть як одноманітність у порівнянні із яскравими образами його партнерів, приміром, П. Саксаганським» (с. 247). Але той самий Мар'яненко (1954) зауважує, що лише згодом оцінив створені I. Карпенком-Карим образи як «неперевершені шедеври» (с. 247). І. Волошин (1973) також наголошує, що I. Карпенкові-Карому закидали «понижену емоційну віддачу через те, що він уникав афектації, підкресленої подачі тексту» (с.114). Проте, звертаючи увагу на такі його акторські риси, як «психологічна заглибленість, відхід від театрального пафосу у героїчних ролях, відмова від декламації та мелодраматичного надриву» (Волошин, 1973, с. 112), критик доходить висновку, що його «простота і реалізм вражали більше, ніж патологічні карикатури багатьох сучасних йому акторів» (Волошин, 1973, с. 116).

Вочевидь, своєрідна виконавська манера I. Карпенка-Карого з часом відобразиться і в осо- 
бливостях його драматургічної манери, надавши й іншим акторам нових можливостей.

Найяскравіше ці еволюційні процеси простежуються на прикладі їхнього творчого тандему із М. Заньковецькою. Один із найавторитетніших дослідників тї творчості С. Дурилін (1982) акцентує увагу на тому, що саме драматургічний матеріал, наданий I. Карпенком-Карим, 3 актуальним для нього відходом від шаблону та більш глибоким опрацюванням людського характеру, «сприяв розкриттю іï акторської природи» (с. 131). Так, граючи Харитину з «Наймички», до речі на гастролях у Москві й Петербурзі саме ця вистава зазнала найбільшого успіху; попри зовнішню схожість сюжетів і характерів, М. Заньковецька ні в чому не повторювала Олену з п'єси М. Кропивницького «Глитай, або ж Павук». Це можна пояснити не лише багатогранністю таланту актриси, а й тим, що I. Карпенко-Карий вперше у своїх твоpax запропонував не лише соціальний, а й психологічний тип героя (Дурылин, 1982).

До речі, М. Заньковецьку у «Наймичці» під час гастролей у Москві бачив А. Чехов, якому в іiі виконанні імпонували якраз ті пресловуті простота і стриманість у почуттях. Недарма він, за словами актриси, наголошував, що «в неї багато милого, задушевного, чеховського» (Бобир, 1984, c. 19). Відтак доволі органічним видається вже звичне порівняння М. Заньковецької зі ще однією «чеховською» актрисою, представницею російської акторської школи, - В. Комісаржевською, яких, при очевидній різниці творчих індивідуальностей, поєднують простота і природність манери гри (Бобир, 1984). Це порівняння двох акторських особистостей можна поставити у ширший контекст, де з'являються постаті драматургів, які надали надалі новий матеріал для еволюціонування засобів сценічної виразності. Коли йдеться про взаємовплив творчості А. Чехова і В. Комісаржевської, прийнято завважувати про те, що «єдність світосприйняття цих двох художників спричинила їхню ідейну, стилістичну близькість» (Португалова, 1947, с. 338). Здається, справедливо говорити і про певну ідейно-естетичну близькість двох драматургів-реформаторів.

Звичайно, порівнюючи творчість цих двох авторів, слід враховувати соціокультурний контекст, у якому формувався і працював кожен з них, але спорідненість їхніх пошуків у процесі реформування сучасної для них театральної практики стає очевидною.

Драматургічна творчість і А. Чехова, і його старшого сучасника I. Карпенка-Карого не завж- ди синхронізується із мистецькими тенденціями у контексті свого часу. Ті естетичні зсуви, які відбуваються у їхніх творах, ніби випереджають час свого створення, актуалізуючи проблеми сценічної практики.

Така «несвоєчасність» п’єс цих авторів викликала у сучасників дискусії щодо їхньої сценічності.

Саме питанню сценічності п'єси Чехова «Чайка» присвячена одна із праць авторки статті, в якій ця проблема розглядається в контексті двох історичних подій: провалу вистави за «Чайкою» в Александринському театрі та іiі реабілітації у театральному світі завдяки постановці на сцені МХТ (Шестакова, 2020). Лише після мхатівського реваншу Чехова стали дедалі рідше звинувачувати у «нехтуванні вічними законами драми і мистецтва взагалі» (Чудаков, 1971, с. 196). В цілому очевидно, що драматургічні відкриття і А. Чехова, й I. Карпенка-Карого випереджали рівень якості тогочасного акторського ансамблю, через що і актуалізувалися подібні проблеми.

Так само неодноразово, але трохи раніше смертний вирок несценічності виносили і творам I. Карпенка-Карого. Навіть його соратник М. Старицький закидав йому «нехтування законами сцени» (Коломієць, 2008, с. 66). Саме ця проблематичність 3 часом в обох випадках проявить потужний потенціал цієї драматургії, що дасть можливість говорити про створення нової системи театрального мислення А. Чеховим та розширення уявлення про можливості української драматургії та сцени завдяки діяльності I. Карпенка-Карого.

I. Карпенко-Карий, сформувавшись у традиціях музично-драматичної вистави, народженої в надрах театру корифеїв, сам започаткував створення суто драматичної вистави (Коломієць, 2008), що стало прецедентом для тогочасної практики українського театру.

Як і для російського автора, для його творчої манери характерне реалістичне осмислення дійсності 3 мінімізацією сентиментально-романтичних тенденцій. Він починає радикально звільняти свої п’єси від пісень, танців, обрядів, одне слово, тих обов'язкових для театральної естетики театру корифеїв елементів, надаючи, таким чином, нове уявлення про «театральну виразність без мелодраматизму» (Дурылин, 1982, с. 135). І. Карпенко-Карий свідомо намагався «очистити традиційний сюжет від мелодраматизму і етнографізму» (Скрипник, 1960, с. 38), однак обрядова структура не безслідно зникає з його творів, а трансформується: ритми і мелодику пісень, голосінь він вво- 
дить у монологи і діалоги, надаючи їм своєрідної форми (Дурылин, 1982). Останньою п’єсою, в якій мелодраматизм у нього наявний у старій аранжировці, була п'єса «Бурлака» (Скрипник, 1960), що можна вважати даниною старій театральній традиції. До речі, у творчості А.Чехова також була п’єса, яку можна вважати свого роду прощанням зі звичним уявленням про театральність. «Іванов», написаний ще за звичними для дев'ятнадцятого століття правилами драматургії, фіналізував певний етап творчості драматурга, після чого й розпочнуться кардинальні трансформації.

Ще однією спільною для цих авторів точкою відліку щодо перетворення драматургії можна вважати деталізовану розробку психології персонажів. Недарма ж п’єси Чехова стали органічним матеріалом на шляху розвитку психологічного театру. У п'єсах Карпенка-Карого також поглиблюється психологізація образів, наприклад, цікавить не сам факт страждання героя або героїні, а дослідження причин цього явища (Дурылин, 1982). Автор пропонує саме психологічне вмотивування вчинків героїв, що дає змогу відійти від звичного образу-маски і шаблону у виконанні. Приміром, в образі Софії з «Безталанної» він «вперше усуває амплуа ingénue dramatique» (Дурылин, 1982, с. 170), відходячи від умовності та схематичності. I саме психологічна глибина стане однією 3 показових рис драматургії А. Чехова, яка навіть у простих водевілях не давала приводу для спрощеності виконання. Так само, як згодом А. Чехов, I. Карпенко-Карий почне відмовлятися у своїх п’єсах від уявлення про життя як серію ефектів, намагаючись подолати канонічність прийомів, що схематизують картину буття.

Особливості конструкції діалогів і монологів у обох авторів також дають підстави говорити про новаторство їхніх методів побудови п'єс. Так, монолог у I. Карпенка-Карого більше нагадує сповідь (Дурылин, 1982), яка вже сама по собі передбачає діалогічність. І якщо у п’єсах А. Чехова однією з особливостей стає монологізм діалогу, який відокремлює персонажів одне від одного, автономізує до такого собі психологічного аутизму, то структура монологу в Карпенка-Карого, навпаки, передбачає наявність незвичної для цієї форми спілкування фігури «партнера», до якого він звернений.

Формування побутового середовища в контексті художнього світу кожного із авторів можна вважати ще одним важливим елементом у розгляді проблеми оновлення драматургії. Попри деталі- зований, інколи аж занадто, побутовий світ героїв, у А. Чехова, на відміну від загальноприйнятої на час написання творів літературної традиції, очевидна «нестійка, амбівалентна роль матеріального побуту — крім затишку і комфорту, він може бути серйозною загрозою на шляху розвитку людини, поглинаючи своєю вульгарністю» (Зингерман, 1979, с. 76-77). Він у А. Чехова відіграє, почасти, роль психологічної характеристики героїв, відчуттів, які формують певні ситуації. У І. Карпенка-Карого побут також позбавлений сюжетотворчої сили. На думку театрознавиці В. Заболотної (1995), «він конкретизує ситуацію, характер, але його можна уникнути в постановках заради філософського узагальнення» (с. 36). У п'єсах обох драматургів не лише формується середовище, а й створюється атмосфера, що є набагато важливішим і складнішим завданням. Побутові, на перший погляд, подробиці набувають значення деталей-знаків, які надають нових можливостей у зображенні людини, явища (Чудаков, 1971).

Драматургія А. Чехова починається 3 водевілів. «Саме через них можна отримати доступ до головних чеховських п'єс» (Зингерман, 1979, с. 50). Звичайно, йдеться не лише про хронологію його творчості, а й про витоки естетичних принципів. І. Карпенка-Карого, як і А. Чехова цікавила трансформація традиційного жанру комедії у так звану «серйозну комедію», яка передбачала трагікомічний злам, ускладнюючи структуру (Скрипник, 1960). Така нова розстановка акцентів також стане показовим елементом трансформаційних процесів їхньої драматургії.

У порівнянні творчого доробку драматургів привертає увагу той факт, що деяких персонажів I. Карпенка-Карого можна розглядати як прототипи чеховських героїв. Для прикладу, головний герой п'єси «Хазяїн» як соціально-психологічний тип, здається, набуде розвитку в образі Лопахіна 3 «Вишневого саду»; Іван Барильченко із «Суєти» викликає стійкі асоціації із характером Трєплєва 3 чеховської «Чайки», а у «Житейському морі» він же трансформується, набуваючи рис героя-антипода Тригоріна. I. Карпенко-Карий запропонував обертонні характери, де, звичайно, ще немає тієї чеховської неоднозначності, яку тому закидатимуть вже після написання «Іванова», але український драматург створює палітру складних, індивідуалізованих психотипів.

Навіть у суто формальних засобах організації драматургічного матеріалу можна простежити певну спадкоємність. П'єси I. Карпенка-Карого вважаються більш динамічними, ніж твори його 
сучасників, через те, зокрема, що «саме він скорочує п’ятиактні твори до чотирьох дій» (Скрипник,1960, с. 74) і саме таку систему, як пам'ятаємо, буде використовувати при побудові своїх п’єс А. Чехов.

Висновки. Попри, на перший погляд, несхожість двох таких митців, як А. Чехов й І. Карпенко-Карий, спорідненість їхньої творчості спостерігається на більш глибинному рівні. Кожного 3 них, виходячи $з$ особливостей контексту, можна розглядати як автора, у творах якого підбивалися підсумки однієї системи театральних цінностей і розпочиналося формування інших законів сценічної виразності. Спадщина кожного з них ознаменувала собою важливий естетичний перехід, адже інтегруючим елементом, що дає можливість розглядати їхні постаті в одному семантичному ряду, була реформаторська спрямованість їхніх творів. Оновлення драматургічного матеріалу проявилося у таких основних аспектах:

- Деталізованій розробці психології персонажів

- Особливостях конструкції діалогів і монологів

- Зміні ролі побутового середовища у контексті художнього світу автора

- Трансформації традиційного жанру комедії

- Формуванні нового уявлення про сценічність п'єси

Так, А. Чехов, творчі інтенції якого формуються в надрах європейської «нової драми», котра саме в його творах і досягає піку свого розвитку, стає предтечею нових естетичних систем, актуальних вже у XX столітті, зокрема театру абсурду.

Драматургію ж І. Карпенка-Карого теж можна розглядати у масштабі не лише індивідуального творчого шляху, а й як важливий етап розвитку українського театрального мистецтва. Він здійснює якісно значущий перехід від традицій корифеїв, які сформували його мистецьку особистість, до європейської модерної драматургії початку $\mathrm{XX}$ століття. Завдяки цьому органічно форматується, скажімо, асоціативний ряд між його останніми п’єсами та першими драматургічними досвідами В. Винниченка.

Таким чином, якщо розглядати дві зазначені постаті в рамках проблеми оновлення драматургії та сценічної практики, обравши не лише ідейно-тематичний ракурс, а й акцентуючи нові принципи організації драматургічного матеріалу, очевидним стає новаторський потенціал, що розмикає базові для кожного з них естетичні системи і розкривається у нових тенденціях театрального мислення.

\section{Бібліографія}

Бобир, О. (1984). Марія Заньковецька у колі діячів російської культури. Київ: Товариство Знання УРСР. 32 с.

Волошин, І. (1973). Акторська майстерність корифеӥв. Київ: Мистецтво. $182 \mathrm{c}$.

Дурылин, С. (1982). Мария Заньковеиякая: 1854-1934: Жизнь и творчество. Киев: Мистецтво. $447 \mathrm{c}$.

Заболотна, В. (1995). Деякі особливості драматургії І. Карпенка-Карого. Матеріали всеукраӥнської міжвузівської наукової конферениії. Кіровоград: Народне слово. C. $35-37$.

Зингерман, Б. (1979). Очерки истории драмы ХХ века. Москва: Наука. 390 с.

Зингерман, Б. (2001). Театр Чехова и его мировое значение. Москва: РИК Русанова. 432 с.

Коломієць, Р. (2008). Традииї̈, канони і новації украӥнського театру: Початок XIX- початок XX cm. (Книга I). Київ: Інтертехнологія. $136 \mathrm{c}$.

Марьяненко, И. (1954). Прошлое украинского театра. Москва: Искусство. 248 с.

Португалова, М. (1947). Чехов и Комиссаржевская. Е. Кузнецов (Ред.). Русские классики и театр. С. 335-353. Ленинград-Москва: Искусство.

Скрипник, І. (1960). Іван Карпенко-Карий: Літературний nортрет. Київ: Державне видавництво художньої літератури. $108 \mathrm{c}$.

Чудаков, А. (1971). Поэтика Чехова. Москва: Наука. 289 с.

Шестакова, Д. (2020). «Чайка» А. П. Чехова: перші театральні досвіди. До питання сценічності п’єси. Науковий вісник Київського національного університету театру, кіно і телебачення імені I. К. Карпенка-Карого. Зб. наук. праць. Вип. 26. Київ: КНУ театру, кіно і телебачення імені І. К. Карпенка-Карого. С. 43-48.

\section{References:}

Bobyr, O. (1984). Mariia Zankovetska u koli diiachiv rosiiskoi kultury [Mariia Zankovetska in the circle of figures of Russian culture]. Kyiv: Tovarystvo Znannia URSR. 32 p. [in Ukrainian]

Chudakov, A. (1971). Poetika Chekhova [Poetics of Chekhov]. Moskva: Nauka. 289 p. [in Russian]

Durylin, S. (1982). Mariya Zankovetskaya: 1854-1934: Zhizn i tvorchestvo [Mariya Zankovetskaya: 1854-1934: Life and art]. Kiev: Mistetstvo. 447 p. [in Russian]

Kolomiiets, R. (2008). Tradytsii, kanony i novatsii ukrainskoho teatru: Pochatok XIX - pochatok XX st. [Traditions, canons and innovations of the Ukrainian theater: The beginning of the XIX - the beginning of the XX century]. (Knyha 1). Kyiv: Intertekhnolohiia. 136 p. [in Ukrainian]

Maryanenko, I. (1954). Proshloe ukrainskogo teatra [The past of the Ukrainian theater]. Moskva: Iskusstvo. 248 p. [in Russian]

Portugalova, M. (1947). Chekhov i Komissarzhevskaya [Chekhov and Komissarzhevskaya]. Ye.Kuznetsov (Red.). Russkie klassiki i teatr. Leningrad-Moskva: Iskusstvo. P. 335-353. [in Russian]

Shestakova, D. (2020). «Chaika» A. P. Chekhova: pershi teatralni dosvidy. Do pytannia stsenichnosti piesy [«The Seagull» by A. P. Chekhov: first theatrical experiences. To the question of the theatrical effectiveness of play]. Naukovyi visnyk Kyivskoho natsionalnoho universytetu teatru, kino $i$ telebachennia imeni I. K. Karpenka-Karoho. Vyp.26. Zb. nauk. prats. Kyiv: KNU teatru, kino i telebachennia imeni I. K. Karpenka-Karoho. P. 43-48. [in Ukrainian]

Skrypnyk, I. (1960). Ivan Karpenko-Karyi: Literaturnyi portret [Ivan Karpenko-Kary: Literary portrait]. Kyiv: Derzhavne vydavnytstvo khudozhnoi literatury. 108 p. [in Ukrainian] 
Voloshyn, I. (1973). Aktorska maisternist koryfeiv [Acting skills of coryphaeus]. Kyiv: Mystetstvo. 182 p. [in Ukrainian]

Zabolotna, V. (1995). Deiaki osoblyvosti dramaturhii I.KarpenkaKaroho [Some features of I. Karpenko-Kary's drama]. Materialy vseukrainskoi mizhvuzivskoi naukovoi konferentsii. Kirovohrad: Narodne slovo. P. 35-37. [in Ukrainian]
Zingerman, B. (1979). Ocherki istorii dramy XX veka [Essays on the history of drama of the 20th century]. Moskva: Nauka. 390 p. [in Russian]

Zingerman, B. (2001). Teatr Chekhova i ego mirovoe znachenie [Chekhov Theater and its global significance]. Moskva: RIK Rusanova. 432 p. [in Russian]

\section{Daria Shestakova}

\section{A. Chekhov and I. Karpenko-Karyi: reform of drama and stage practices. The main aspects}

Abstract. In this work the figures of A. Chekhov and I. Karpenko-Kary are considered as playwrightsreformers. The author takes into account the socio-cultural context in which each of them was formed and worked. The exploration compares the drama of A. Chekhov and I. Karpenko-Kary and identifies the main aspects of the reform.

As a result of the analysis the innovative potential becomes obvious, which opens the basic aesthetic systems for each of them and reveals new trends in theatrical thinking.

Keywords: plays by I. Karpenko-Karyi, A. Chekhov's dramaturgy, theatrical reform, theatrical effectiveness of play, psychologization of the image.

\section{Шестакова Дарья Викторовна}

\section{А. Чехов и И. Карпенко-Карый: реформа драматургии и сценической практики.} Основные аспекты

Аннотация. В этой работе предлагается рассмотреть личности А.Чехова и И.Карпенко-Карого как драматургов-реформаторов. Автор учитывает социокультурный контекст, в котором формировался и работал каждый из них. В исследовании происходит сравнительный анализ драматургического наследия А.Чехова и И.Карпенко-Карого и определяются основные аспекты реформы.

В результате анализа очевидным становится новаторский потенциал их драматических произведений. Он размыкает базовые для каждого из них эстетические системы и раскрывается в новых тенденциях театрального мышления

Ключевые слова: пьесы И. Карпенко-Карого, драматургия А. Чехова, театральная реформа, сценичность пьесы, психологизация характера. 